\title{
JAN PAWE⿺ II A 1600. ROCZNICA NAWRÓCENIA ŚW. AUGUSTYNA
}

Cechą wielkich geniuszy jest to, że ich myśli się nie starzeją, przeciwnie znaczenie ich rośnie z upływem lat. Do takich geniuszy należy św. Augustyn: największe autorytety moralne powołują się wciąż na Biskupa Hippony. Myśl św. Augustyna jest stale obecna i ceniona w całym Kościele. Już Celestyn I (422432) zaliczał go do „najlepszych Mistrzów Kościoła”1. Leon XIII (1878-1903) głosił chwałę jego nauki filozoficznej², a Pius XI (1922-1939) mówił o jego cnotach i doktrynie ${ }^{3}$. Z kolei Paweł VI (1963-1978) podkreślał, że w Augustynie jaśnieją nie tylko wszystkie przymioty Ojców, lecz w jego dziełach zawiera się cała starożytna myśl, z której biorą początek sposoby myślenia przenikające całą tradycję doktryny w następnych wiekach ${ }^{4}$. Jan Paweł II, idąc śladami swoich wielkich poprzedników, pragnął:

„ażeby jego [tj. Augustyna] doktryna filozoficzna, teologiczna i duchowa była studiowana i rozpowszechniana, dzięki czemu mógłby on również obecnie nauczanie w Kościele kontynuować [...] równocześnie pokorne i genialne, którego treścią jest Chrystus i miłość"

Z okazji 1600-lecia nawrócenia i chrztu Augustyna w Liście Apostolskim Augustinum Hipponensem tenże papież mówił o nawróceniu Augustyna z Tagasty, o Augustynie Doktorze, genialnym twórcy filozofii chrześcijańskiej, niezmordowanym promotorze doskonałości duchowej i religijnej oraz

${ }^{1}$ Caelestinus, Epistola ad episcopos Galliarum Apostolici verba (431) 2, 3, PL 50, 530; por. S. Longosz, Papież Celestyn I o św. Augustynie, VoxP 8 (1988) z. 14, 47-48.

2 Por. Leo XIII, Encyklika Aeterni Patris (4 VIII 1827), w: Acta Leonis XIII, I, Roma 1881, 270.

${ }^{3}$ Por. Pius XI, Encyklika Ad salutem humani generis (22 IV 1930), AAS 22 (1930) 233; jej przekład por. VoxP 6 (1986) z. 11, 441-475.

${ }^{4}$ Por. Paweł VI, Przemówienie do członków zakonu Augustianów z okazji inauguracji Instytutu Patrystycznego „Augustinianum” (4 V 1970), AAS 62 (1970) 426; jego przekład por. VoxP 3 (1983) z. 4, 15-20.

5 Jan Paweł II, Przemówienie do profesorów i studentów Patrystycznego „Augustinianum” wygłoszone w siedzibie Instytutu (8 V 1982), AAS 74 (1982) 800; jego przekład por. VoxP 3 (1983) z. 4, 21-28. 
Ojcu chrześcijańskiej Europy, Biskupie Hippony jako o wspaniałym pasterzu i obrońcy nieskażonej wiary, wreszcie o aktualności św. Augustyna w świecie współczesnym 6 .

1. Nawrócenie świętego Augustyna. Drogę nawrócenia Augustyna z Tagasty znamy z jego dzieł, które napisał przed chrztem w Kasycjakum: Contra academicos, De beata vita, De ordine, Soliloquia i z później napisanych, ale najbardziej znanych z jego pism Confessiones, w których czyni wyznanie o gorącym pragnieniu poznania Boga:

„Pragnąłem Cię poznać tak, jak ja jestem poznany [...]. Ty prawdę umiłowałeś [...]. W moich wyznaniach pragnę ją w sercu wypełnić wobec Ciebie, a w tej książce wobec wielu świadków"?

Augustyńska spowiedź wobec Boga dokonuje się w wielkiej ciszy, a zarazem rozgłośnie, bo „choćby język milknął, serce woła”. Jan Paweł II stwierdza, iz Wyznania świętego Augustyna są bardzo poczytne również obecnie, ponieważ swym bogactwem introspekcji i uczuć religijnych poruszają ludzkie umysły i je niepokoją. Mają w ten sposób wpływ nie tylko na wierzących, ale również na niewierzących ${ }^{9}$.

Papież pisze, iż Augustyn mimo umiłowania mądrości, do której zapłonął miłością po przeczytaniu książki Cycerona Hortensjusz, popełnił trzy błędy. Pierwszy z nich polegał na błędnym ujęciu relacji zachodzącej między wiarą i rozumem, jakby należało wybierać między nimi. Polegał więc na pewnym racjonalizmie, pod wpływem którego Augustyn był przekonany, że należy pójść nie za tymi, którzy nakazują wierzyć, lecz za tymi, którzy nauczają prawdy ${ }^{10}$. Drugi polegał na domniemanej różnicy między Chrystusem i Kościołem, z czego niektórzy wyciągali wniosek, że dla pełniejszego zjednoczenia się z Chrystusem, należy zerwać z Kościołem ${ }^{11}$. Wreszcie trzeci polegał na pragnieniu uwolnienia się od świadomości grzechu nie przez odpuszczenie na skutek działania łaski, lecz przez negację ludzkiej odpowiedzialności w samym akcie grzesznika ${ }^{12}$.

2. Święty Augustyn Doktor Kościoła. Całym procesem nawrócenia Augustyna kierowało umiłowanie prawdy. W De Trinitate wyznaje: ,porywa mnie

${ }^{6}$ Por. Augustinum Hipponensem (28 VIII 1986), AAS 79 (1987) 137-170, jego przekład por. OsRomPol 7 (1986) nr 9, s. 3-9, przedruk VoxP 8 (1988) z. 14, 7-46.

7 Confessiones X 1, 1, CCL 27, 155, NBA 1, 298, tłum. Z. Kubiak: Swięty Augustyn, Wyznania, wyd. trzecie poprawione, Warszawa 1987, 218.

${ }^{8}$ Tamże X 2, 2, Kubiak s. 219.

9 Por. Augustinum Hipponensem, VoxP z. 14, s. 9.

${ }^{10}$ Por. tamże, VoxP z. 14, s. 10-11; zob. Augustinus, De beata vita 1, 4, NBA 3, 186.

11 Por. Augustinum Hipponensem, VoxP z. 14, s. 11.

12 Tamże. 
dociekanie prawdy"13. Augustyńskie studium obejmowało jednocześnie dwa kierunki: z jednej strony zgłębianie wiary katolickiej, z drugiej jej obrona przed tymi, którzy ją odrzucali, to jest manichejczykami i poganami, lub błędnie ją wyjaśniali, to jest manichejczykami, pelagianami i arianami.

a) Rozum i wiara. Na pierwsze miejsce wysuwa się problem rozumu i wiary, problem, z którym miał trudne chwile w młodości, dlatego wracał do niego z cała mocą umysłu i uczucia. Chodzi bowiem o sprawę relacji zachodzących między rozumem i wiarą. Jest to problem wciąż aktualny, ponieważ chodzi o uniknięcie dwóch skrajności: fideizmu, który gardzi rozumem, i racjonalizmu odrzucającego wiarę. Augustyn był całkowicie posłuszny wierze, ale też nie pomniejszał rozumu. W następujący sposób podsumował kazanie poświęcone wierze:

„Intellege, ut credas, verbum meum; crede, ut intellegas, verbum Dei - Zrozum moje słowo, abyś mógł w nie uwierzyć; wierz w słowo Boga, abyś mógł je zrozumieć" ${ }^{14}$.

Problem rozumu i wiary poruszony w Liście Apostolskim Augustinum Hipponensem papież pogłębił później w encyklice Fides et ratio, przytaczając aż dwa augustyńskie teksty odnoszące się do wiary:

„Sama wiara nie jest niczym innym jak przyzwoleniem myśli [...]. Wiara, jeśli nie jest myśleniem, nie istnieje" 15 .

A na innym miejscu:

„Jeśli usuwamy przyzwolenie rozumu, usuwamy wiarę, ponieważ bez przyzwolenia rozumu nie można wierzyć. Wiara i rozum są jak dwa skrzydła, na których duch ludzki unosi się ku kontemplacji prawdy"16

- tak oto zaczyna papież swą encyklikę Fides et ratio. Te dwa skrzydła posiadał Augustyn i wykorzystał je w swej twórczości pisarskiej.

W wielkim dziele De civitate Dei problem rozumu i wiary stał się problemem wiary i kultury. Augustyn podejmując ten wielki wysiłek, aby stworzyć i rozwinąć kulturę chrześcijańską, dał w tym dziele wierny wykład chrześcijańskiej doktryny, ukazał możliwość przejęcia pogańskiej kultury w tych punktach, w których to jest możliwe, zwłaszcza w zakresie filozofii, wreszcie ukazał w chrześcijańskiej

${ }^{13}$ De Trinitate I 5, 8, NBA 4, 18: ,rapimur amore indagandae veritatis”, tłum. M. Stokowska, POK 24, 87.

14 Sermo 43, 9, NBA 29, 760; por. Augustinum Hipponensem, VoxP z. 14, s. 17-20.

15 De praedestinatione sanctorum 2, 5, NBA 20, 228: ,ipsum credere, nihil aliud est, quam cum assensione cogitare [...] fides si non cogitetur, nulla est", por. Fides et ratio 79, w: Encykliki Jana Pawła II, Kraków 2006, 1168.

${ }^{16}$ De fide, spe et caritate 7, 20, NBA 6/2, 498: „At si tollatur assensio fides tollitur, quia sine assensione nihil creditur", por. Fides et ratio 79, tamże. 
doktrynie elementy prawd i wartości nieprzemijających, które przejęte przez chrześcijaństwo zostały udoskonalone i uszlachetnione ${ }^{17}$. Dlatego też dzieło De civitate Dei czytano nie tylko w średniowieczu, ale także i dziś jest ono czytane w duchu pogłębienia spotkania chrześcijaństwa z kulturą narodów.

b) Bóg i człowie k. Drugi ważny problem, który Augustyn ustawicznie zgłębiał, a Jan Paweł II w swym Liście Apostolskim zauważa, dotyczy relacji: Bóg - człowiek. Augustyn te dwie prawdy stale łączył. Naświetlił potrójne pojęcie Boga: „Istnienie”, to jest Jego ,jest”, z którego wszystko, co jest, zostało wyprowadzone przez akt stworzenia, „Prawda” oświecająca umysł człowieka, aby mógł w sposób pewny poznać prawdę, „Miłość”, z której pochodzi i do której zmierza wszelka prawdziwa miłość. Największy jednak wysiłek włożył Augustyn w studiowanie obecności Boga w człowieku. Odnajduje Boga, który jest „wewnętrzny - wieczny"18, najbardziej odległy i obecny ${ }^{19}$. Człowiek nie może widzieć siebie inaczej jak w swojej relacji do Boga. Cenne jest tu jego zdanie: „Creasti nos, Domine ad te et inquietum est cor nostrum donec requiescat in te" ${ }^{20}$ Człowiek jest magna quaestio ${ }^{21}$, której to kwestii Augustyn poświęca wiele czasu i miejsca.

c) Chrystus i Kościół. Chrystus i Kościół stanowią punkt centralny całej myśli teologicznej Biskupa Hippony. Kościół nie może być oddzielony od Chrystusa. Jedynym pośrednikiem między Bogiem i ludźmi jest Chrystus, człowiek - Bóg. Jako jedyny Pośrednik i Odkupiciel, Chrystus jest głową Kościoła, Chrystus i Kościół są jedną osobą mistyczną, całym Chrystusem. Augustyn daje różne definicje Kościoła: Kościół jest wspólnotą sakramentów, wspólnotą świętych, wspólnotą zbawionych, jest Matką i Nauczycielką, jest dziewicą: matką z powodu miłości, dziewicą - z powodu nienaruszalności wiary, której strzeże, broni, naucza:

„Mamy więc Ducha Świętego, jeśli miłujemy Kościół, a kochamy go, jeśli pozostajemy z nim w łączności i miłości ${ }^{22}$ [...]. Jesteśmy przekonani, bracia, że każdy w takiej mierze ma Ducha Świętego, w jakiej kocha Kościół Chrystusa"23.

17 Por. De civitate Dei II 29, 1-2, NBA 5/1, 156, 158 i 160; A. Eckmann, Kultura klasyczna uśw. Augustyna, VoxP 6 (1986) z. 10, 45-60.

18 Por. Confessiones IX 4, 10, NBA 1, 264 i 266.

${ }^{19}$ Por. tamże I 4, 4, NBA 1,6 i 8.

20 Tamże I 1, 1, NBA 1, 4.

21 Tamże IV 4, 9, NBA 1, 90.

22 In Johannis Evangelium tractatus 32, 8, NBA 24/1, 696 i 698: „Habemus ergo Spiritum Sanctum, si amamus Ecclesiam; amamus autem, si eius compage et caritate consistimus”, por. Augustinum Hipponensem, VoxP z. 14, 24-30.

23 Tamże, NBA 24/1, 696: „Credamus, fratres, quantum quisque amat Ecclesiam Christi, tantum habet Spiritum Sanctum”, por. Augustinum Hipponensem, tamże. 
d) Wolność i ła s k a. Wolność jest fundamentem całej chrześcijańskiej wiedzy o człowieku:

„Ten, który cię stworzył bez ciebie, nie usprawiedliwia cię bez ciebie. Tak więc stworzył nie wiedzącego o tym, usprawiedliwia chcącego" 24 .

Łaska jest potrzebna do usunięcia przeszkód, na jakie napotyka wola, aby mogła odrzucić zło i czynić dobro. Aby odetchnąć wolnością, trzeba pokonać dwie przeszkody: ignorancję i słabość. Wolność jest nieodłączna od prawdy i miłości.

e) Miłość i uniesienie ducha. Augustyn wzywa do miłości ${ }^{25}$. To ona, jak zaznacza również papież, stanowi istotę i normę chrześcijańskiej doskonałości ${ }^{26}$. Miłość nie może być oddzielona od pokory: „gdzie pokora, tam i miłość"27. Miłość jest istotą każdej cnoty: cnota bowiem jest niczym innym jak uporządkowaną miłością ${ }^{28}$ i darem Boga. Z miłości zrodziło się w Augustynie pragnienie kontemplowania rzeczy Bożych, co jest właściwe mądrości ${ }^{29}$.

3. Święty Augustyn Pasterz Kościoła. Kontemplacja, modlitwa szła w życiu Augustyna $\mathrm{w}$ parze $\mathrm{z}$ działaniem. Te dwa aspekty pozornie przeciwstawne uzupełniały się wzajemnie. Jan Paweł II w swym Liście Apostolskim Augustinum Hipponensem zalicza św. Augustyna do „największych pasterzy Kościoła”30. Działalność duszpasterska Biskupa Hippony obejmowała trzy poszerzające się koncentrycznie kręgi: Kościół lokalny w Hipponie, Kościół Afrykański i Kościół Powszechny ${ }^{31}$.

Biskup miał wiele zajęć, bardzo różnych i uciążliwych. W konkretnej czynnej pracy pasterskiej w Kościele Hipponeńskim ważne miejsce zajmowało nauczanie. Słowo Boże było chlebem, którym Biskup hojnie obdarowywał wiernych z wielką miłością (omni studio caritatis) ${ }^{32}$. Najbardziej istotną częścią

${ }^{24}$ Sermo 169, 11, 13, NBA 31/2, 794: „Qui ergo fecit te sine te, non te iustificat sine te. Ergo fecit nescientem, iustificat volentem", por. Augustinum Hipponensem, VoxP z. 14, s. 30-35.

25 Por. De catechizandis rudibus 4, 8, NBA 7/2, 194.

${ }^{26}$ Por. De natura et gratia 70, 84, NBA 17/1, 484 i 486, por. Augustinum Hipponensem, VoxP z. 14 , s. $35-39$.

27 In Johannis Epistolam ad Parthos prologus, NBA 24/2, 1636: „ubi humilitas, ibi caritas”.

${ }^{28}$ Por. De civitate Dei XV 22, NBA 5/2, 438: „Unde mihi videtur, quod definitio brevis et vera virtutis ordo est amoris".

29 Por. De Trinitate XII 15, 25, NBA 4, 498; zob. też A. Eckmann, Siła mądrości według świętego Augustyna, w: Lumen Christi tantum in Ecclesia, red. T. Paszkowska, Lublin 2005, 445-455.

30 Por. Augustinum Hiponensem, VoxP z. 14, s. 39-41, spec. 39.

${ }^{31}$ Por. tamże; zob. też A. Eckmann, Św. Augustyn-duszpasterz, VoxP 7 (1987) z. 12-13, 464480 i 8 (1988) z. $15,306-313$.

32 Por. Epistola 95, 6, NBA 21, 898. 
jego posługiwania było udzielanie sakramentów świętych. Warunki otoczenia jednak zmuszały go do załatwiania spraw, w których trudniej jest dostrzec charakter nadprzyrodzony i przyjąć je jako część posłannictwa pasterskiego, jak rozstrzyganie sporów zwaśnionych diecezjan potrzebujących jego pomocy. Wielką troską otaczał też ubogich, odwiedzał wdowy i sieroty doświadczone cierpieniem $^{33}$. Ubodzy zawsze znajdowali miejsce $w$ jego sercu. Pomagając ubogim sięgał także do dochodów Kościoła i ofiar wiernych ${ }^{34}$. Kiedy zaś fundusze, którymi rozporządzał, nie wystarczały, stawał się ambasadorem ubogich, prosząc o pomoc dla nich swoich diecezjan ${ }^{35}$. Kiedy zbliżała się zima, polecał wiernym okryć w ubogich nagość Chrystusa ${ }^{36}$, w ważniejszych potrzebach sięgał nawet po święte naczynia ${ }^{37}$.

Niezwykłą troską otaczał również prowadzone przez siebie seminarium duchowne, zwane przez niego monasterium clericorum, któremu przyświecało dobro wiernych i dobro Kościoła. Zwracając się do wiernych mówił o nim: „Vobiscum hic vivimus, et propter vos vivimus" ${ }^{38}$. W augustyńskim seminarium istotne miejsce zajmowała modlitwa, ale oprócz praktyk religijnych Biskup podkreślał w wychowaniu religijnym potrzebę pracy fizycznej i studium. Jedynie zajęcia duszpasterskie, a zwłaszcza sprawowanie sakramentów świętych, uwalniały od obowiązków pracy fizycznej i dawały według niego prawo do utrzymania z ołtarza.

Drugim kręgiem duszpasterskiej działalności Biskupa Hippony był Kościół Afrykański. Nie tylko głosił w kościołach poza swoją diecezją kazania, ale także prowadził dysputy z braćmi odłączonymi. Wszelkimi sposobami szukał dialogu z donatystami, wierząc w skuteczność szczerej i otwartej dyskusji. Konferencja w Kartaginie była uwieńczeniem jego wysiłku ${ }^{39}$. Dzięki dyskusjom z donatystami i swemu przepowiadaniu, pogłębił naukę katolicką o naturze sakramentów i Kościoła. Pasterska działalność św. Augustyna wykraczała daleko poza granice Afryki i rozprzestrzeniła się na cały Kościół. Jednym z narzędzi jego oddziaływania były jego własne dzieła i listy. Ponadto Biskup Hippony prowadził dla dobra Kościoła Powszechnego dysputy z manichejczykami, pelagianami, arianami i poganami ${ }^{40}$.

${ }^{33}$ Por. Possidius, Vita S. Augustini 27, PL 32, 56-57; zob. też A. Eckmann, Troska o ubogich w nauczaniu i działalności świętego Augustyna, VoxP 16 (1996) z. 30-31, 161-182.

${ }^{34}$ Por. Possidius, Vita S. Augustini 23-24, PL 32, 52-54.

35 Por. Sermo 61, 12, NBA 30/1, 240 i 242.

36 Por. Sermo 25, 8, NBA 29, 484.

${ }^{37}$ Por. Possidius, Vita S. Augustini 24, PL 32, 54.

38 Sermo 355, 1, 1, NBA 34, 244; zob też. A. Eckmann, Teologia kaptaństwa w pismach św. Augustyna, VoxP 13-15 (1993-1995) z. 24-29, 131-160.

39 Por. Gesta cum Emerito Donatistarum Episcopo, CSEL 53, 179-196; Breviculus collationis cum Donatistis, CSEL 53, 37-92.

${ }^{40}$ Por. A. Eckmann, Dialog świętego Augustyna ze światem pogańskim w świetle jego korespondencji, Lublin 1987. 
4. Augustyn a ludzie współcześni. Augustyńskie przesłanie zdecydowanie przekracza obszar afrykański, w którym on żył. Kieruje się ono ku wierzącemu i ku człowiekowi każdego czasu, ale takiemu, który nie żyje zwrócony ku sobie samemu, lecz otwiera się na otaczający go świat. Augustyn śle swoje orędzie do człowieka krytycznego, ale szczerze szukającego, który nie zadawala się łatwo czymkolwiek, lecz stawia pytania. Augustyn ofiaruje gorące pragnienie i wołanie o to, co się nie kończy, przez otwarcie się na Boga i zwrócenie się ku temu, co bardziej antyczne i prawdziwe: „fecisti nos Domine ad te et inquietum est cor nostrum, donec requiescat in te" ${ }^{41}$. Pragnie on dzielić się chrześcijańskim doświadczeniem głosząc radość ze spotkania z Chrystusem, który daje sens życiu i odnawia egzystencję człowieka. Augustyn chce oświecić i zaspokoić racje serca, gdzie człowiek jest prawdziwie sobą.

Człowiek wyznacza sobie drogę i wskazuje cel. Chcąc osiągnąc postęp duchowy rozmyśla i koryguje siebie, jak to wyznaje Biskup Hippony pod koniec swego życia:

\begin{abstract}
„Obecnie piszę sprostowanie całej swej twórczości literackiej, aby wykazać, że sam czasami zmieniałem swe zapatrywanie. Usiłuję w tej książce udowodnić, że moja działalność piśmiennicza, poczynając od niedoskonałych pierwocin, rozwinęła się, jak sądzę, dzięki zmiłowaniu Bożemu. Powiedziałbym bardziej bezczelne niż prawdziwe zdanie twierdząc, że w tym wieku doszedłem do nieomylności w swych pismach" ${ }^{42}$.
\end{abstract}

Augustyn dzięki darom umysłu i serca, szczerej pokorze i gorącej modlitwie badał trudne i skomplikowane problemy bez zejścia z drogi wiary i prawdy, jak sam o tym mówi w końcowym wyznaniu De Trinitate:

„Panie, Boże nasz, wierzymy w Ciebie, Ojca, Syna i Ducha Świętego [...]. Trzymając się tej zasady wiary kierowałem całym swoim wysiłkiem; nie szczędziłem własnych sił i liczyłem na Twoją pomoc, aby szukać Ciebie. Pragnąłem widzieć siłami umysłu to, w co uwierzyłem. Wiele dociekałem, wiele pracowałem. Panie, Boże mój, jedyna nadziejo moja, wysłuchaj mnie, abym nie uległ zmęczeniu i nie zaniechał poszukiwania Ciebie, ale bym zawsze gorliwie szukał oblicza Twego. Ty sam daj mi siły na poszukiwanie, Tyś bowiem pozwolił, abym Cię znalazł, Tyś mi dał nadzieję, że odnajdę Cię coraz więcej. Przed Tobą jest moc i niemoc moja: moc zachowaj, niemoc ulecz. Przed Tobą jest wiedza moja i niewiedza; w bramie przez Ciebie uchylonej przyjmij mnie. U drzwi zamkniętych, kiedy pukam, otwórz mi. Niech o Tobie pamiętam, niech Ciebie zrozumiem, niech Ciebie pokocham. Wzmocnij we mnie te trzy dziedziny, aż mnie do cna odtworzysz" ${ }^{43}$.

${ }^{41}$ Confessiones I 1, 1, NBA 1, 4; por. Augustinum Hipponensem, VoxP z. 14, s. 41-45; A. Eckmann, Święty Augustyn dziś, VoxP 21 (2001) t. 40-41, 305-316.

${ }^{42}$ De dono perseverantiae 21, 55, NBA 20, 384, thum. W. Eborowicz, POK 27, 376.

${ }^{43}$ De Trinitate XV 28, 51, NBA 4, 716 i 718, tłum. Stokowska, POK 25, 458. 
Na końcu listu Augustinum Hipponensem papież Jan Paweł II wskazuje na aktualność Augustyńskiego przesłania, zwracając uwagę na różne kategorie osób szukających prawdy - teologów, myślicieli, ludzi nauki, rządzących i młodych oraz konkluduje:

„Przypomniałem nawrócenie świętego Augustyna i przedstawiłem ogólnie doktrynę tego niezwykłego męża, którego synami i uczniami czujemy się w jakiś sposób wszyscy, zarówno w Kościele, jak i na całym Zachodzie. Wyrażam na nowo z głębi serca życzenie, aby jego doktryna była studiowana i szeroko rozpowszechniana, a pasterska gorliwość stała się wzorem do naśladowania, dzięki czemu nauka tak wielkiego uczonego i pasterza będzie kwitnąć i rozwijać się w Kościele i w świecie dla pożytku wiary i kultury" "44.

\title{
QUAE A JOHANNE PAULO II DE SANCTO AUGUSTINO IN EPISTULA APOSTOLICA AUGUSTINUM HIPPONENSEM SCRIPTA SINT
}

\author{
(Argumentum)
}

Johannes Paulus II in Epistula Apostolica Augustinum Hipponensem saeculo XVI a conversione Sancti Augustini expleto pro hoc Ecclesiae reddito dono per eamque universo hominum generi, mirabili illa ex conversione gratiarum Deo actionem agit. Ex animo exoptat, ut magisterium Sancti Doctoris investigatum etiam subtilius longe late cognoscatur studiumque eius pastorale imitando ubique repetatur, quo tanti magistri ministrique doctrina inter homines vigere pergat et fides proficiat et cultus ipse humanus.

44 Augustinum Hipponensem, VoxP z. 14, s. 45; por. A. Eckmann, Symbol Apostolski w pismach świętego Augustyna, Lublin 1999; tenże, Święty Augustyn dla kultury Europy, w: VII Kongres Teologów Polskich, t. 3: Kościót w życiu prywatnym. Teologia polska i europejska wobec wyzwań, Lublin 2005, 279-312. 